\title{
Variant CCR5 Delta 32 and The Possible Protective Factor Against COVID-19
}

\author{
Rafael S Knack*, Taliê Hanada and Renata S Knack \\ Hospital Israelita Albert Einstein, Brazil \\ *Corresponding author: Rafael S Knack, Hospital Israelita Albert Einstein, Albert Einstein, 627, São Paulo, Brazil
}

\begin{tabular}{ll}
\hline ARTICLE INFO & ABSTRACT \\
\hline
\end{tabular}

Received: December 15, 2020

Published: 慧 December 22, 2020
Abbreviations: HIV: Human Immunodeficiency Virus; HCV: Hepatitis C Virus; HBV: Hepatitis B; WNV: West Nile Virus; TBEV: Tick-Encephalitis Virus

Citation: Rafael S Knack, Taliê Hanada, Renata S Knack. Variant CCR5 Delta 32 and The Possible Protective Factor Against COVID-19. Biomed J Sci \& Tech Res 32(4)2020. BJSTR. MS.ID.005296.

\section{Introduction}

The CCR5 gene is known to be responsible for inducing the inflammatory process and leukocyte chemotaxis in a wide range of infectious diseases, including Human Immunodeficiency Virus (HIV), Hepatitis C Virus (HCV) and Hepatitis B (HBV), West Nile Virus (WNV), Tick-Encephalitis Virus (TBEV) [1]. Avariant of the CCR5 gene, characterized by a common deletion of 32 base pairs(bp), in the derivative region, leads to the formation of the delta 32 CCR5, significantly reducing, a surface expression of the receptor, which may impact resistance against viral diseases. Currently the delta 32 variant is the target of a study for HIV gene therapy [2]. In December 2019, a new type of coronavirus, SARS-CoV-2, was discovered, characterized by atypical pneumonia consisting of fever, dry cough and progressive dyspnea [3]. The virus quickly spread across the world, leading to a worldwide high-impact pandemic [4]. Recently, Aditya K Panda et al. [5], raised a question, pointing out the possible distribution of mutant CCR5 delta 32 with the differential infection and the mortality rate in COVID-19. So, would the variant of the CCR5 delta 32 gene be a protective factor against SARS-CoV-2? In this present report, we brought the case of a patient, SLRL, male, 59 years old, resident in Brazil, being attended by the medical team of Hospital Israelita Albert Einstein in the city of São Paulo, who presented homozygosity for variant CCR5 delta 32 and was tested positive for SARS-CoV-2 infection, through the qualitative RT-PCR test for coronavirus, on October 20,2020. The genetic test performed was the analysis of polymorphisms which identified the presence of two delta32 alleles in the CCR 5 gene, supported by the rs333 polymorphism. On October 17,2020 , the patient sought medical attention, reporting a fever and general malaise. He was instructed to perform the RT-PCR test for COVID-19, which was positive. There was no pharmacological conduct, since the symptomatic picture had a course of only two days in duration, remaining asymptomatic during the rest of the infectious period. From this report, it can be inferred that the possible protective character of the mutant CCR5 delta 32 gene for COVID-19 infection cannot be confirmed. Opening the opportunity for more population-based genetic association studies to be encouraged to validate new findings.

\section{Competing Interests}

The authors declare no competing interests.

\section{References}

1. Sajid Husain RG (1998) First report of a healthy Indian heterozygous for D32 mutant of HIV-1 co-receptor-CCR5 gene. Gene 207(2): 141-147.

2. RS Klein (2008) A moving target: the multiple roles of CCR5 in infectious diseases. J Infect Dis 197(2): 183-186. 
3. Takahashi TL (2020) Pharmacogenomics of COVID-19 therapies. Genom Med 5: 35.

4. JR Delanghe MS (2020) ACE Ins/Del genetic poly- morphism and epidemiological findings in COVID-19. Clin Chem Lab Med 58(7): 11291130.

\section{ISSN: 2574-1241}

DOI: $10.26717 /$ BJSTR.2020.32.005296

Rafael S Knack. Biomed J Sci \& Tech Res

(c) (P) This work is licensed under Creative

Submission Link: https://biomedres.us/submit-manuscript.php
5. Aditya K Panda AP (2020) CCR5 $\Delta 32$ minorallele is associated with susceptibility to SARS-CoV-2 infection and death: An Tepidemiological investigation. Clinica Chimica Acta 510: 60-61.

$\begin{array}{ll}\text { BIOMEDICAL } & \text { Assets of Publishing with us } \\ \text { RESEARCHES } & \text { - Global archiving of articles } \\ \text { - Immediate, unrestricted online access } & \text { - Rigorous Peer Review Process } \\ & \text { - Authors Retain Copyrights } \\ & \end{array}$

